\title{
A Vision Towards Indigenous Education Sovereignty in Northwestern Ontario
}

\author{
Melissa Oskineegish and Leisa Desmoulins
}

Lakehead University

\section{Authors' Note}

We acknowledge the guidance and funding from the National Centre for Collaboration in Indigenous Education. Their support allowed us to do this research with educators throughout NWO and made this paper possible. Chi miigwetch

Correspondence concerning this article should be addressed to Melissa Oskineegish, Email: mmoberly@1akeheadu.ca or Leisa Dsmoulins 1desmoul@1akeheadu.ca

\begin{abstract}
To support the calls for Indigenous education sovereignty by the National Indian Brotherhood (1972) and the Assembly of First Nations, (1988), in this paper we explore Indigenous education as envisioned by six educators and knowledge holders in northwestern Ontario. Educators from six different schools and programs who took part in a national project called the National Centre for Collaboration in Indigenous education shared their descriptions and visions of Indigenous education. Findings reveal Indigenous pedagogies that align with Lee and McCarty's (2017) theoretical framework of culturally sustaining and revitalizing pedagogies to promote and support Indigenous education sovereignty. Their visions include pedagogies grounded in the need for equitable education; Indigenous-led instruction for land-based teachings, traditional practices and languages; and, community-based accountabilities. Their visions illustrate that a deeper understanding of the localized and nationhood contexts of Indigenous sovereignty over education is missing and needed in the ongoing movement towards educational sovereignty.
\end{abstract}

Keywords: Indigenous sovereignty; Indigenous education; culturally sustaining and revitalizing pedagogies

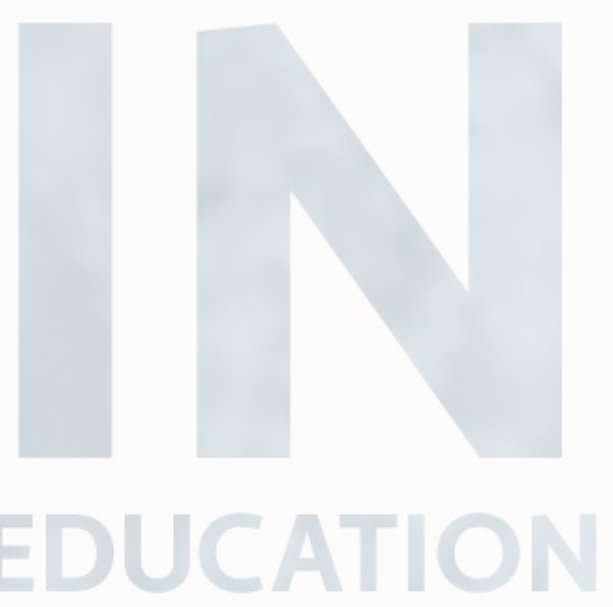




\section{A Vision Towards Indigenous Education Sovereignty in Northwestern Ontario}

In Canada, the movement towards Indigenous education sovereignty stems, in part, from the policy paper, Indian Control of Indian Education. Released in 1972 and presented to the Minister of Indian Affairs and Northern Development, the National Indian Brotherhood (NIB) called for educational sovereignty and the rights of First Nations communities to repatriate ownership and control of their children's education. The call for sovereignty included training and hiring Indigenous educators, implementing culturally relevant curriculum, and providing educational facilities and resources equal to non-Indigenous communities. In 1988, the Assembly of First Nations (AFN), formerly known as NIB, reiterated this call for ownership and control of education in the report titled Tradition and Education: Towards a Vision of Our Future. Since then, many communities have gained band-controlled education, whereby First Nations' leadership and their education authorities have administrative control over school operations, staff hiring, programming, and curriculum (Nishnawbe Aski Nation [NAN], 2012). AFN and its communities have long argued that band-controlled education does not meet the spirit and intent of First Nation control of First Nation education, which is to repatriate education (AFN, 2010). In 2018, First Nations communities in Ontario signed an Agreement-in-Principle with the Federal Government to commit to ongoing negotiations towards First Nations' authority over education within their communities (NAN, 2018). Agreements in principle represent the next step toward First Nations' sovereignty over education.

To support the movement towards Indigenous education sovereignty, in this paper we share the aspirations and hopes for Indigenous education as envisioned by Indigenous educators in Northwestern Ontario (NWO). We argue that these educators' visions exemplify Indigenous pedagogies that align with McCarty and Lee's (2014) description of culturally sustaining and revitalizing pedagogies (CSRP) that promote and support Indigenous educational sovereignty. Educators' visions include the following three aspects: the ongoing need for equitable funding for First Nations education; Indigenous-led instruction for land-based teachings, traditional practices and languages; and community-based accountabilities.

\section{Situating the Study and Indigenous Education in Northwestern Ontario}

The NCCIE is a national project that began at First Nations University in 2017. Its vision is to

highlight innovative and exciting examples of Indigenous education from across the country, celebrating the dedicated work by communities to strengthen Indigenous education for all generations. We [NCCIE] connect people at the grassroots level where education is delivered and knowledge is passed on. (NCCIE, 2019)

To implement its vision to collaborate with Indigenous educators to strengthen Indigenous education, the NCCIE support network sought out Regional Leads within universities across Canada. Regional Leads were tasked to hire and mentor Indigenous and non-Indigenous graduate students to conduct Indigenous research approaches and connect to Indigenous educators within their regions (NCCIE, 2019).

Lakehead University in Thunder Bay housed the research team for the NWO region, which is one of 16 regions across Canada and one of four regions within Ontario. NWO is a geographically large area that spans from Michipicoten First Nation in the southeast to the Manitoba boundary in the west. NWO has a growing number of First Nations schools in rural and remote communities and in urban centres such as Thunder Bay, Kenora, Sioux Lookout, and 
Fort Frances. Most community-based (i.e. on-reserve) schools offer early childhood education (ECE) programs and formal schooling from Kindergarten to Grade 8 (and rarely to Grade12, the final year of secondary education in Ontario). Some schools in urban centres offer secondary schooling (Grades 9 to 12). Thunder Bay is an educational hub for many First Nations communities: most First Nations lack secondary schools. Without options in their communities, many parents send their children to larger centres to gain a high school diploma. Within these contexts, we share the perspectives of six Indigenous educators that lead Indigenous educational programs across the NWO region. Their experiences, perspectives, and visions for Indigenous education are tied to issues of self-determination and sovereignty as First Nation communities and educational programs establish their own visions for Indigenous education. We introduce them in the Methodology section of this article.

As non-Indigenous authors, we now introduce ourselves before we situate this work within the literature. Melissa Oskineegish, a team member for NCCIE in NWO, began her teaching career in a fly-in First Nation community in northern Ontario. As a classroom teacher, she was guided by experienced and knowledgeable educators who mentored her to develop relevant and ethical pedagogies and curriculum in her teaching practices. Her experience directly influenced her research on effective strategies for non-Indigenous educators to develop culturally responsive pedagogies. Leisa Desmoulins is a non-Indigenous teacher educator who uses culturally sustaining and revitalizing pedagogies in her courses within the Department of Aboriginal Education in a Faculty of Education in NWO. She honed relationships through 15 years of community-led research within the region. She has served as Regional lead for NCCIE in NWO for three years. During that time, she mentored Indigenous and non-Indigenous students to conduct Indigenous research approaches that respond and give back to Indigenous communities. We both hold relational accountability to our families and communities as we work and live within NWO.

\section{Literature Review}

Cultural asset pedagogies, such as culturally responsive schooling (Castagno \& Brayboy, 2008), culturally proficient instruction (Nuri-Robins et al., 2011; Terrell \& Lindsey, 2009), and culturebased education (Demmert, Jr., 2011) emerged as educational strategies for transforming the academic and cultural policies, practices, and pedagogies within schools to affirm and value the cultural heritage of Indigenous students and their tribal communities. In Castagno and Brayboy's (2008) meta-analysis of culturally responsive schooling in the United States between 1980 and 2007, they argued that culturally responsive schooling can have a positive impact on Indigenous students' academic achievements when implemented systematically, institutionally, and over a long term.

The need for cultural asset theories stems from the primary use of schools used as a tool to assimilate Indigenous students into Eurocentric discourses (Battiste, 2013; White \& Peters, 2009). The most prominent example, the Indian Residential School System (IRSS), explicitly and systematically operated to separate and eliminate Indigenous children's connection to their families, languages, ceremonial beliefs, and cultural heritages (RCAP, 1996; TRC, 2015). As Residential Schools closed and students transitioned to day schools, the Eurocentric operation of schools maintained the ongoing forces of colonization and assimilation. Battiste (2013) described the processes and curricula of schooling as rooted in "cognitive imperialism," which perpetuates "white-washing the mind as a result of forced assimilation, English education, Eurocentric humanities and sciences, and living in a Eurocentric context complete with media, books, laws, 
and values" (p. 26). Cultural asset theories aim to transform the Eurocentric, middle-class cultural dominance of schooling by providing strategies and methods for incorporating pluralistic cultural pedagogies (Alim \& Paris, 2017; Hammond, 2015).

In Alim and Paris's (2017) "loving critiques of asset pedagogies" (p. 4), they described how educators can enact cultural asset pedagogies moving forward:

In this work we are committed to envisioning and enacting pedagogies that are not filtered through the glass of amused contempt and pity (e.g., the "achievement gap"), but rather are centered on contending in complex ways with the rich and innovative linguistic, literate, and cultural practices of Indigenous, Black, Latinx, Asian, Pacific Islander, and other youth and communities of color. (p. 2)

Lee and McCarty (2017) take up Alim and Paris's call for culturally sustaining pedagogies and extend the idea to culturally sustaining/revitalizing pedagogies (CSRP) that are grounded in Indigenous knowledges for Indigenous educational sovereignty. They described educational sovereignty as the right to self-determined education. They embed CSRP within "the experiences of Native American peoples [that] have been and are profoundly shaped by a unique relationship with the Federal Government and by their status as tribal sovereigns" (Lee \& McCarty, 2017, p. 102), and combine cultural asset pedagogies with the "sociohistorical and contemporary contexts" (Lee \& McCarty, 2017, p. 62) of Indigenous education.

While McCarty and Lee (2014) wrote about Indigenous sovereignty within an American context, Battiste, Bell, and Findlay (2002) wrote about Indigenous pedagogies embedded within Indigenous knowledges within a Canadian context: "Indigenous knowledge is not sufficiently and appropriately available through books, journals, monographs, theses, or dissertations, or from teachers or university professors" (p. 91). They explained that Indigenous knowledge lives within Indigenous communities.

Barnhardt and Kawagley (2005) provided an example of how Indigenous knowledge lives within communities by sharing a story of enacting "rich and innovative" Indigenous knowledge systems that benefit students' understanding in ways they can relate to:

For example, when choosing an eddy along the river for placing a fishing net, it can be explained initially in the Indigenous way of understanding by pointing out the currents, movement of debris and sediment in the water, the likely path of the fish, the condition of the river bank, upstream conditions affecting water levels, the impact of passing boats, and so on. Once students understand the significance of the knowledge being presented, it can then be explained in Western terms, such as flow, velocity, resistance, turbidity, sonar readings, and tide tables, to illustrate how the modern [sic] explanation adds to the traditional understanding (and vice versa). All learning can begin with what the student and community already know and have experienced in everyday life. (p. 12)

Barnhardt and Kawagley (2005) explained that the purpose of sharing this story is to illuminate how Indigenous students, like all students, "will become more motivated to learn when the subject matter is based on something useful to the livelihood of the community and is presented in a way that reflects a familiar worldview (Battiste, 2002; Kawagley, 1995; Lipka et al., 1998)" (p. 12). Further, Lee and McCarty (2017) asserted that CSRP extends culturally responsive pedagogies by including critical examinations of the "enduring forces of colonization" (p. 62). They define CSRP through the following three action-based components: 
advancing Indigenous sovereignty that "attends directly to asymmetrical power relations" (p. 62); revitalizing and reclaiming linguistic and cultural heritages; and implementing Indigenous community-based accountability. In this paper, we share the descriptions and visions of Indigenous educators in relation to these three components of CSRP, to amplify Indigenous educational sovereignty expressed by Indigenous educators in varied communities and programs across NWO.

\section{Methodology}

An Indigenist approach to research (Rix et al., 2018; Wilson, 2016) guided our work with this study. An Indigenist approach differs from an Indigenous approach because an Indigenist approach is open to anyone who follows its tenets (Wilson, 2016). Cree scholar Shawn Wilson (2016) described it as a strengths-based approach to create an Indigenous vision for the future by and for families and communities. Two tenets of an Indigenist approach at the heart of this research are that the voices, knowledge, experience, and opinions of Indigenous educators and the knowledge holders are the primary informants (Rix et al., 2018), and that relational accountability roots the research approach (Donald, 2012; Wilson, 2016). To uphold participants as the primary informants, NCCIE followed the First Nations principles of ownership, control, access, and possession (OCAP). NCCIE provided guidance to each region on informed invitations and consent forms, a ceremonial gift appropriate to the knowledge holder, and a review process prior to publication on the NCCIE website. Each region determined the specific approaches, gifts, and processes. Wilson (2016) explains that relational accountability exists when researchers "are accountable to and for maintaining healthy relationships" (p. 311). Maintaining healthy relationships for our team meant seeking guidance from Elders, educators and knowledge holders holding ongoing conversations with potential participants to ensure mutual benefit in participation and, adjusting to different approaches in the interview process. Wilson (2016) asserts "I'm not just in these relationships, but rather I am these relationships" (p. 313). For us, this shows relationality - our relationships with participants did not begin with this study in all cases and they extend beyond this study. We are in relation. We describe the specific approaches of NWO next in the methods section.

\section{Methods}

In the first year of the three-year project (November 2017 to April 2018), the Regional Lead for NWO gained approval from Lakehead University's research ethics board. Indigenous and non-Indigenous graduate students in Indigenous education served as Research Assistants for the NWO team. The Regional Lead trained them to follow the interview guide and interview educators (participants) using the video and audio equipment provided by NCCIE. Indigenous knowledge holders and educators from Indigenous communities, schools, and programs in communities across the NWO region were contacted and interviewed. NCCIE researchers for NWO selected many educator/participants through prior and ongoing relationships, a form of relational sampling (Wilson, 2008).

The NWO research team developed and followed specific protocols: They invited participants to partake in the research with a description of the project and commitment requested, provided informed consent and the interview questions prior to the interview, offered a gift of tobacco and an honorarium to all participants, and sent interview previews to participants for approval or changes. Within these protocols researchers and participants engaged in informal conversations and discussed ways to ensure mutual benefit for NCCIE and the 
participant's school or program. Examples of mutual benefit included networking and sharing information about the school or project to a wider audience adding URL's in the video descriptions that linked to the school or project, and offering help towards participants' initiatives. Once participants approved the edited video or audio-taped interviews, a team member from the NWO region uploaded the interview to an NCCIE website. Research Assistants conducted seventeen interviews with educators in the NWO region in Year 1.

Interviewers used an interview guide from NCCIE with four questions:

1. How do you describe your program? (prompts-what is it called, who is it for, aim of the program, how do you measure success?)

2. From your perspective, what is Indigenous education?

3. What is your vision for Indigenous education over the next 10 years?

4. What information, materials, resources do you need to achieve that vision (aside from funding)?

\section{Data Analysis}

The analysis of data was guided by principles of grounded theory (Bryant \& Charmaz, 2007; Creswell, 2014; Savin-Baden \& Major, 2013). Our grounded theory analysis began with initial coding of all interviews that led to the development of multiple categories. A process of constant comparison between participants' experiences, perspectives, and vision followed to generate themes (Savin-Baden \& Major, 2013). For this paper we coded the responses for three of the four questions stated above (i.e., educators' and knowledge holders' descriptions of their schools, programs, or initiatives; their perspective of Indigenous Education; and vision for moving forward), positioning codes within the theoretical framework of CSRP - known as axial coding (Creswell, 2014).

Educators' responses comprise the heart of this paper, as a means for us as teacher educators to learn from Indigenous peoples. We sent each participant the final descriptions and quotes for review. We asked them if they wanted their data included and if they wanted us to use a pseudonym. Three participants are provided with a pseudonym (Peter, Michelle, and Mark), and three responded with specific directions (i.e., one participant requested "D. Kakepetum"). We made all changes that were requested.

\section{Introducing the Educators and Their Programs}

In this section, we introduce each educational program and educator in the order they appear in the Findings section that follows.

\section{Pelican Falls First Nation High School}

Peter is a former principal at Pelican Falls First Nation High School (PFFNHS) in Sioux Lookout, Ontario. PFFNHS is a school for First Nation students from the surrounding communities in the Nishnaabe Aski Nation (NAN), many of which are fly-in communities in the northernmost corner of NWO. The school is part of a family of schools run by NNEC. Notably, PFFNHS is a "private, First Nations controlled and operated [secondary] school" (NNEC, 2014) that "offers unique and culturally relevant educational services to students from 24 First Nations communities" (NNEC, 2014). 


\section{Seven Generations Education Institute}

Brent Tookenay is the Chief Executive Officer at Seven Generations Education Institute (SGEI). SGEI is First Nation owned and operated with locations in Kenora, Fort Frances, and Thunder Bay, Ontario. Originally formed in 1985 as an Education Authority to deliver trade programs and satellite high school classrooms for 10 First Nation communities in the Rainy Lake tribal area (of the Grand Council Treaty 3 Political Territorial Organization), SGEI expanded and grew as it sought to "provide secondary education for Anishinaabeg students who were not being accommodated in the public system, and who were at risk of ending their formal education" (7generations.org, n.d.).

\section{Shkoday Abinojiiwak Obimiwedoon}

Michelle is the Executive Director at Shkoday Abinojiiwak Obimiwedoon. She also oversees the Biwaase'aa program. Shkoday's Aboriginal Head Start program provides early childhood education for off-reserve children aged 18 months to six years who live in the urban centre of Thunder Bay, Ontario. Michelle describes the aim of the program to "teach culture." The Biwaase'aa program is a culture-based program provided within seven schools and one high school in Thunder Bay to youth.

\section{Kiizhik}

Mark is the former principal of an elementary school, Gaagagekiizhik Gakinoo'amaawadiiwi'gamig GaKinoo'amaawasowin, also known as Kiizhik, in Fort Frances, Ontario. The Bimose Tribal Council in collaboration with provincial Education Authorities opened the Kiizhik school as a First-Nation-operated, Anishinaabe school. Kiizhik serves students and families from surrounding First Nations within the Tribal Council. In September 2015, Kiizhik opened with 15 children. Today it offers classes from Kindergarten to Grade 5. Because Kiizhik exists alongside provincial schools in the area and with provincial funding, it has dual accountabilities to the province and its students, their families and communities.

\section{Thomas Fiddler Memorial School}

D. Kakepetum serves as coordinator of elementary school programming at Thomas Fiddler Memorial School, in Sandy Lake First Nation, Ontario. The school is part of the education programs offered to members of Sandy Lake, a fly-in community of 1500 people, 600 $\mathrm{km}$ northwest of Thunder Bay. D. Kakepetum is responsible for a variety of programs within the elementary school-from math and literacy to Introduction to Identity and cultural land-based learning where Elders give guidance for teachers and students (i.e. where ice fishing, rabbit snaring, walking around the trails, shore-line fishing and ice fishing, etc.). She also oversees language programs that Thomas Fiddler Memorial School offers for learners in Kindergarten to Grade 6. Language instructors for students in Grades 1, 2, and 3 use immersion approaches to ground students in the local Oji-Cree language.

\section{Kay-Nah-Chi-Wah-Nung Historical Centre}

Tara Montague served as a former Administrative Manager of the Kay-Nah-Chi-WahNung historical centre, in Rainy River First Nation, Ontario. Kay-Nah-Chi-Wah-Nung means "the place of the long rapids" (Staniforth, 2019). It is commonly known as Manitou Mounds, for its burial mounds on the banks of the rapids. The historical centre is run by the Rainy River First Nation and serves learners from local First Nations as well as the general public who come to the historical centre. The following present their responses and visions. 


\section{Findings}

All of the educators were managers of programs or schools in urban, rural, and remote communities within NWO. From these interviews, three central themes emerged from their visions of Indigenous education: Establishing equitable educational access and opportunities for Indigenous students, especially in technology and academic preparation; Providing Indigenousled pedagogies anchored in Indigenous knowledges through practices such as land-based teachings and culturally sustaining ceremonial and traditional activities; and, integration, flexibility, and valuing of Indigenous pedagogies that acknowledge the whole child - the spiritual, emotional, intellectual, and physical—and within families and communities. We share educators' rich insights into each of these themes in the findings that follow.

\section{Equitable Access to Educational Opportunities}

Peter, former principal of PFFNHS, and Brent Tookenay, C.E.O. at SGEI, both served students and families from surrounding First Nations communities. Peter described Indigenous education as, "Learning your culture, [and] your history." Peter gave as an example, "learning about land and how to live off the land, [and] how we did things a long time ago." At PFFNHS, educators do this "by bringing in educators and guests who can share Indigenous knowledge." By highlighting Indigenous education as grounded in cultural, historical, and inter-generational practices guided by Elders and knowledge keepers, Peter's description places Indigenous knowledges at the core.

Peter shared a two-part vision. The first part was to end wait lists for students to attend his school. He wanted to see Pelican Falls expand in ways "that respond to the vision of communities and students." As one example, he explained that students want the option to take academic courses. Currently, PPFNHS offers applied courses. Because their degree limits them, student graduates from PPFNHS can apply only to college-level programs for further studies. Peter also saw other limitations for students at PFFNHS. Peter wanted, for example, to incorporate technology (e.g., e-learning and other technological resources) so that students of PFFNHS graduate with the same technological knowledge, skills, and abilities as their peers.

Beyond the limitations of students' options within PFFNHS, the second part of Peter's vision for Indigenous Education was for non-Indigenous people to become more aware of the history, culture and values of First Nation peoples:

To make our vision a reality in the non-Native population so they can understand what First Nation people are all about, our connection to the land, our culture, our language and how we strive to connect our young people to success in the non-Native environment. (Peter)

In his vision Peter reiterated the core of Indigenous knowledges-land, culture, and language. Another aspect of his vision involves, "connect[ing] our young people to success in the nonNative environment." Peter's vision is to aid Indigenous students' with success in the broader world once they leave PFFNHS to pursue higher education for themselves and their communities. Peter addressed accountability to the communities PFFNHS serves when he articulated "that [PFFNHS] responds to the vision of communities and students." Peter tied this accountability to improving students' abilities to excel in varied learning environments.

Brent described one unique feature of SGEI's secondary school, which now "serves 15 of the First Nations [communities] in the Treaty 3 area" and uses satellite classrooms with itinerant 
teachers who travel to communities rather than students travelling to attend school. This feature exemplifies "meeting students where they're at," in a place-based sense (Styres, Haig Brown, \& Blimkie, 2013). Along with SGEI's practice of itinerant teachers travelling to communities, students have opportunities to learn from local Elders and knowledge keepers within their communities.

For Brent, Indigenous education provides "opportunities [for students] to learn language and culture" in their home communities. In a secondary school, this includes "opportunities to take courses where [Indigenous] content is incorporated in all courses," said Brent.

Moving forward, Brent said he envisions students at SGEI having "those same opportunities given to mainstream schools" which include the same course options for "technology, dual credits [that allow high school students to take college courses to earn both secondary and post-secondary credits], and e-learning" available to students in provincially-run secondary schools. Brent's vision for technological opportunities highlighted the longstanding inequalities in school facilities for Indigenous students (NAN, 2012).

Through their visions, Peter and Brent reflect McCarty and Lee's (2014) socio-historical realities of schooling, the first aspect of educational sovereignty. Peter and Brent envision their students having the same opportunities as their peers in publicly funded schools in Ontario. These opportunities include academic and other courses relevant for students access to technology and dual credits and opportunities that $21^{\text {st }}$ century learners require to move into postsecondary learning.

\section{Indigenous-Led Instruction}

Indigenous-led instruction requires Indigenous educators, including Elders and knowledge keepers who serve as language and cultural guides (AFN, 2010; Barnhardt \& Kawagley, 2005; Battiste, 2002; NIB, 1972). Indigenous-led instruction is essential to knowing one's culture and teachings and practicing culture through connections to land and language (AFN, 2010; Battiste, 2002; Cajete, 1999; Styres et al., 2013). Michelle and Mark shared ideas about the centrality of Indigenous-led instruction for students and their families within their programs.

Michelle addressed the socio-historical contexts of Indigenous education and the need to include Indigenous educators who connect to land:

[Students] need to be educated correctly of what happened. Ideally, it would be Indigenous people teaching it to everyone. To do the true teachings that we were here on this land - this is our land - and to have the educators teaching it.

Michelle supported the elimination of pan-indigenous and culturally disconnected curriculum. She expressed concern over previous curriculum that was not localized, stating that "they weren't utilizing Elders to teach what was happening here. There was some, they would invite an Elder or a guest on June $21^{\text {st }}$ to teach a little bit." June 21 is National Indigenous Peoples Day in Canada; however, these lessons included only material culture, such as, "how to make a dream catcher, or can you make earrings - these are important but not the only part of our culture," said Michelle. Michelle expressed the need for cultural and experiential teachings from and with Elders and knowledge keepers who are familiar with land-based practices and other spiritual aspects of culture, including language, land-based practices, and ceremonies. Shkoday's 
Biwaase'aa program represented the beginning of this process with its in-school cultural presentations.

For Indigenous education, Michelle envisioned Indigenous pedagogical practices: "For educators in schools to provide Indigenous ways of teaching, we need to see it and do it instead of opening the book about culture, we need hands-on experience," she said. Michelle's vision directly connected to curricula and pedagogies that connect to land and local culture.

Mark shared that Kiizhik School is "a cedar lodge for learning." He talked about Indigenous education from an Anishinaabe perspective. Mark described education as rooted in culture and language:

It's learning to be Anishinaabe. We talk about culture; we talk about language and the resources. What's important, what should we learn, what shouldn't we learn. Each and every person has something to offer, whether it be life experiences or education. And it's being open to those types of teachers, or different religions, whether it be First Nation, non-Native, its being open to that, that's what I think Anishinaabe education is. It's not just in a book, its everything that we do, how we treat each other. ... It's Anishinaabe Bimaadiziwin (The Anishinaabe life).

Mark expressed a belief that educators at Kiizhik school model "Anishinaabe Bimaadiziwin" for students by how they conduct themselves. They are role models. He noted that, "being Anishinaabe is not just something on the wall; it's living it!" Mark's idea of "living your culture" ensures that culture is grounded in Anishinaabe knowledge through Elders, ceremonies, pedagogies, curricula, Anishinaabe language instruction, and more and infused through the school's courses and curricula.

Mark shared his vision for all, acknowledging that this grounding in one's Anishinaabe identity helps to determine who they are and their purpose in life. And that formal schooling is not the only path or the right path for everyone, as Mark stated:

Learning the language, knowing who you are, and that springboard to other education ... Not everyone will want to gain an education, just as long as they know it's there [for them] and as long as they're happy in the decisions they've made. We need to celebrate our different skills. With this school I hope the kids learn about Anishinaabe, their culture. And the teachers to learn more about the language.

Mark said that Anishinaabe culture cannot be learned from a poster on the wall; rather, it is an embodied process of coming to know oneself and their place in the world that one gains through practices, as Anishinaabe Bimaadiziwin. He reinforced the praxis of Indigenous education, Anishinaabe Bimaadiziwin, when he grounded his vision in students knowing who there are, the gifts they have, and determining their own purpose at Kiizhik.

Through their visions, Michelle and Mark activate McCarty and Lee's (2014) revitalizing pedagogies by infusing local communities' linguistic and cultural practices into daily learning at Shkoday and Kiizhik schools, respectively. Their visions show the importance that their communities place on changing schools into space where Elders, knowledge keepers, and language speakers serve as language and cultural guides for the students and their families. Both of them see the value in living the culture through hands-on experiences for teachers and students alike. Michelle tempers her vision by acknowledging, "Ideally it would be Indigenous 
people teaching it to everyone." Both Michelle and Mark sought to bring Indigenous-led instruction into their schools that align with pedagogical practices.

\section{Pedagogical Practices That Align With Indigenous Instruction}

Pedagogical practices are embedded within Indigenous knowledge systems. Iseke and Desmoulins (2015) describe Indigenous knowledge systems as "integrated epistemological systems taught through Indigenous pedagogies that support an understanding of an integrated world and our places within it" (p. 31). These broader systems include Indigenous ways of knowing, philosophies, and values that undergird pedagogical practices (Barnhardt \& Kawagley, 2005; Battiste, 2013; Castellano, 2000; Dei, 2011; Ermine, 1998; Hampton, 1995).

D. Kakepetum and Tara described Indigenous education within their contexts and their visions moving forward. D. Kakepetum explained how she saw culture-based learning and OjiCree language learning come together:

Land-based and language come together when you're out on the land and you have an Elder with you and the Elder talks in their language. They [students] get in touch with their Native language. Their culture is stronger with language. That's how I feel about Native language.

Her feelings about Native language reflected Peter's conceptualization of the land-culturelanguage nexus described above. Michelle also stated the need for cultural and experiential teachings from and with Elders and knowledge keepers.

Further, D. Kakepetum explained her conceptualization of Indigenous education, bringing in intergenerational learning, and the need for knowing who you are. She reiterated the importance of language within the school's curriculum:

To me, Indigenous education started way back with our grandparents and our parents... [They taught us that] everyone needs education. And then part of being Indigenous, it reflects who you are; it reflects us as First Nations, what we bring to young people, and who we are. And that I think is very important you know to be role models for the benefit of our young people, our children. And to continue on with the education and plus learning about who they are, too. Having that language and knowledge of who they are, it makes a big impact of being a First Nations. That's what I think.

Her ideas about knowing who you are as a First Nations person and educators serving as role models for students echo Mark's ideas of teachers as role models for students and the link between Indigenous-led instruction and Indigenous pedagogies localized through place.

When D. Kakepetum shared her vision, she circled back to these ideas of Elders as educators to pass on knowledge of culture and language to the next generation:

I guess this is where we need our Elders and our resources to make our Native language and culture to be continued, I guess, by our young people. And to pass it along from what we learned and then they can carry it on for the next 10 years or the next 20 years so they can pass it along to their children too.

She explained how this happens through Indigenous pedagogies of storytelling:

We need storytellers, too. We need our Elders to be more involved. We do have our Elders involved in our education here. But the more we have it [storytellers and Elders in 
the school] would make an impact on the young people. They'll see that it is really important for who they are and for their learning.

D. Kakepetum saw intergenerational learning through Elders and storytelling as central to teaching and learning.

Tara worked at Kay-Nah-Chi-Wah-Nung Historical Centre. The site is open year-round while the hours of operation change depending on the season. When the Historical Centre is open "visitors go through, work with the tour guide, learn some [socio-historical and cultural] contexts, learn protocols, and learn about what happened in the area," said Tara. While this is like classroom learning, there is an outdoor, experiential aspect of the programming. Tara continued,

Then, they go outside - guided by a knowledge keeper through the property (Long Sioux). They learn about [burial] Mounds. They learn about preservation and respect. Burial mounds practices - to offer tobacco to the spirits, put down soil on the burial mounds. They learn about Ojibwe ways.

The purpose of the centre is for Elders to maintain the story of Manitou Mounds as local history. The centre embodies transformative Indigenous pedagogies for its visitors because "it changes mindsets. It changes perceptions. And now there's a greater appreciation [among the public and community members] for what took place in this area," said Tara.

Manitou Mounds privileges place and is part of its creation story (Staniforth, 2019). For this reason, Tara saw Manitou Mounds as a success story within Indigenous education because of the land-based learning that happens there. She explained, "Experiential land-based activities are a really great example of Indigenous education... there's the education of the culture. There's the education of the history. And framing it all."

For Indigenous education, Tara asserted that more could be done for youth for their improved future through stronger governance. She explained:

Are we talking about educating Indigenous people? ... And how are we educating Indigenous people? I think we all agree to focus on the youth. Because we obviously want to have hope that the [education for] youth will improve where we haven't. I think Indigenous education is very broad and it comes back to the theme of governance.

The focus for Tara was on governance connected to First Nations sovereignty. McCarty \& Lee (2014) describe tribal sovereignty as "the right of a people to self-government, self-education, and self-determination, including the right to linguistic and cultural expressions according to local languages and norms (Lomawaima \& McCarty, 2006; Wilkins \& Lomawaima, 2001)" (p. 102). At Manitou Mounds historical centre, Elders and members of the Rainy River First Nation teach community members and visitors about the mounds through Indigenous pedagogies.

In her vision, Tara sees the community as a strengthened approach through collaboration to expand Indigenous education into a larger movement among Indigenous groups with shared goals:

A lot of us are working on the same mission but we're all charging forth in these separate areas. I feel like if we merged - merged of all these great talents and the great intentsand formed them into one movement. It seems like it's still disconnected. We have a great example of Seven Gens Learning Institute [sic] and yet, I'm guilty of this, we're not 
working together. How can we bridge that? So that we're pooling our resources and we're not having to reinvent the wheel and we're not duplicating in the educational realm. We're all working together better somehow.

Tara expressed her vision of "working together better somehow" as a way to strengthen Indigenous education within the communities in the area.

Through their visions, D. Kakepetum and Tara activate McCarty and Lee's (2014) sovereignty over education through pedagogical practices that align with Indigenous instruction. They described Indigenous pedagogical practices grounded in Indigenous knowledge systems. These practices use place-based (land and water) practices that rely on ancestors and Elders as instructors and follow traditional cultural practices, while passing along these place-based practices to future generations.

\section{Discussion}

For the discussion, we return to McCarty and Lee's (2014) and Lee and McCarty's (2017) three aspects of CSRP: advancing Indigenous sovereignty that "attends directly to asymmetrical power relations" (p. 62); revitalizing and reclaiming linguistic and cultural heritages; and, implementing Indigenous community-based accountabilities. We connect each of these aspects to the educators' visions to consider how they envision Indigenous sovereignty over education.

\section{Socio-historical Realities as Equitable Access to Educational Opportunities}

The educators' visions for Indigenous education highlight what is missing for Indigenous students today and what they envision for their students. Some participants shared ideas about resources and educational opportunities for students that are available to their peers in provincially run schools. As examples, Brent wanted his students to have the technology opportunities that their peers in provincially funded schools in Ontario have, while Peter sought more academic level courses taught at the school. Many schools in NWO enroll students in the applied stream. This limits students' opportunities for advanced coursework and their ability to apply for post-secondary studies at university. Sadly, Peter's example of limiting Indigenous students' options for coursework and its implications illustrates the legacy of colonization and asymmetrical power defined in CSRP, which we turn to next.

Peter and Brent provided some examples of socio-historical contexts (Lee and McCarty, 2017) in Ontario that show inequitable funding and resources for Indigenous students that attend Indigenous schools. One significant example of structural inequity occurred in 1972 when the Federal Government agreed to but did not devolve control over education to First Nations communities. The Federal Government's failure to devolve has had repercussions for Indigenous learners for 45 years. Further examples (i.e. the Federal Government's 2\% cap on funding for Indigenous schools from 1997 to 2016, and the ongoing issues of limited secondary school programming for students that Peter raised) illuminate why the Auditor General (2018, as cited in Sholey, 2018) called Federal Government programs for Indigenous peoples an "incomprehensible failure." These socio-historical contexts counter "the development of a sense of self in students; respect [for] individual, collective, and cultural knowledge; and [the ability to] "cultivate a sense of community and social responsibility (Dei, 2011)" (Iseke \& Desmoulins, 2015, p. 49). The educators' visions for students and their families and communities reflect the socio-historical contexts that hinder student success within their schools. These schools 
experience inequities for funding and resources in comparison to their counterparts in provincial schools.

\section{Revitalizing and Reclaiming Linguistic and Cultural Heritages Through Indigenous-Led Instruction}

A second theme that emerged from educators' visions is the importance of Indigenousled instruction that integrates cultural teachings, perspectives, and practices. Michelle and Mark both highlighted the importance of teaching and learning accurate, localized, Anishinaabe knowledge from local Elders, knowledge-keepers, and speakers of the local dialects of Anishinaabe. Tara described cultural practices and teaching that connect to place. This vision illuminates the need for Indigenous communities to repatriate education for their communities.

Battiste (2002) asserted that universities should view, "Elders, knowledge keepers, and workers who are competent in Aboriginal languages and knowledge as living, educational treasures. These individuals comprise a functioning Aboriginal university based on Indigenous knowledge and pedagogy" (p. 21). Local Elders and knowledge keepers are key to Indigenous knowledges and pedagogies and, most importantly, to passing along knowledge and ways of doing to the next generation. As D. Kakepetum stated, this is "so that they [the young ones today] can pass it along to their children, too."

Michelle explained the connections between Indigenous educators and Indigenous education when she said, "For educators in schools to provide Indigenous ways of teaching, we need to see it and do it... we need hands-on experience." Mark also reiterated the importance of teachers and learners coming together to learn within an Indigenous education approach. He explained, "It's learning to be Anishinaabe .... Being Anishinaabe is not just something on the wall; it's living it!" These educators help us understand that Indigenous knowledges and pedagogies need activation. This activation occurs when learning is connected to Elders, knowledge keepers, language speakers, the land, and culture. Educators start from what students know and the place they come from to connect to concepts within the formal school curriculum.

\section{Implementing Indigenous Community-Based Accountability as Pedagogical Practices}

The educators shared their description of Indigenous education and their visions for Indigenous education within each of their schooling contexts. One thing that comes through all of them is their heart connection to Indigenous education: their visions for students, families, and their communities. Brent and Mark hold accountabilities back to the First Nations communities they serve. The Seven Generations Educational Institute that Brent runs also has accountabilities to members in the urban centres of Kenora, Fort Frances, and Thunder Bay. As the principal, Peter is accountable to the Ministry of Education and the First Nations communities. He explicitly stated his accountability to the 24 First Nations communities that send students to his school, although the education provided by the schools is governed through the Education Act of Ontario and its regulations. He envisioned the high school expanding in ways "that respond to the vision of communities and students." Peter tied accountability to improving students' abilities to excel in all learning environments. D. Kakepetum and Tara's educational programs run in the First Nations communities of Sandy Lake and Rainy River, respectively. Like Brent, Mark, and Peter, they share responsibility back to their communities. The educators' visions reflect what McCarty and Lee (2014) call revitalizing pedagogies, which serve "the needs of Indigenous communities as defined by those communities" (p. 103). Several educators shared 
accountabilities to the Ontario Ministry of Education (OME): all shared accountabilities back to their communities.

\section{Conclusion}

The educational system founded in colonial assimilative practices does not serve the needs of Indigenous communities who seek Indigenous education sovereignty, while band-aid solutions have existed for too long (Battiste, 1998; Kirkness, 1998). Educators from six Indigenous schools and programs across NWO shared descriptions of their programs and their visions. Their visions unveil a call for Indigenous pedagogies that are grounded within the contexts of their communities and the longstanding need for equitable education; employ Indigenous knowledges that anchor Indigenous-led instruction and pedagogies for land-based teachings, traditional practices, and languages that hold cultural and sacred knowledge; and implement Indigenous community-based accountabilities. The educators' visions illustrate that they seek to apply localized and nationhood contexts of learning for their students, families, and communities. Their work in schools shows how they are serving their communities while being accountable to the OME wherever necessary. Meeting OME requirements ensures that their students have options, if they choose to continue with post-secondary learning. When participants seek agreements in principle for their schools, they acknowledge that their desire for full sovereignty over education is a longer-term goal in the ongoing movement towards educational sovereignty. The educators' visions illuminate how they are forging a path toward sovereignty over education for students and their families, as well as the communities to which they are accountable. We acknowledge their efforts for Indigenous students and for those who have yet to enter school. 


\section{References}

7generations.org. (n.d.). Seven Generations Education Institute. www.7generations.org

Alim, H. S., \& Paris, D. (2017). What is culturally sustaining pedagogy and why does it matter? In D. Paris \& H. S. Alim (Eds.), Culturally sustaining pedagogies: Teaching and learning for justice in a changing world (pp. 1-24). New York, NY: Teachers College Press.

Assembly of First Nations (AFN). (2010). First Nations control of First Nations education: It's our vision, it's our time. Ottawa, ON. https://www.afn.ca/uploads/ files/education/3. 2010_july_afn_first_nations_control_of_first_nations_education_final_eng.pdf

Assembly of First Nations (AFN). (1988). Tradition and education: Towards a vision of our future: A declaration of First Nations jurisdiction over education. Ottawa, ON. https://www.afn.ca/uploads/files/education/7._1988_december_afn_tradition_and_educat ion-_a_declaration_on_fn_jurisdiction_over_education.pdf

Barnhardt, R., \& Kawagley, A. O. (2005). Indigenous knowledge systems and Alaska Native ways of knowing. Anthropology and Education Quarterly, 36(1), 8-23. doi:10.1525/aeq.2005.36.1.008

Battiste, M. (1998). Enabling the autumn seed: Toward a decolonized approach to Aboriginal knowledge, language, and education. Canadian Journal of Native Education, 22(1), 1627. https://pdfs.semanticscholar.org/42d8/a953f3d8db24d7a 0ed029e07affa4d663966.pdf

Battiste, M. (2002). Indigenous knowledge and pedagogy in First Nation education: A literature review with recommendations.

https://www.afn.ca/uploads/files/education/24.2002 oct marie battiste indigenouskno wledgeandpedagogy_lit_review_for_min_working_group.pdf

Battiste, M. (2013). Decolonizing education: Nourishing the learning spirit. Saskatoon, SK: Purich.

Battiste, M., Bell, L., \& Findlay, M. L. (2002). Decolonizing education in Canadian universities: An interdisciplinary, international, Indigenous research project. Canadian Journal of Native Education, 26(2), 82-95. https://eric.ed.gov/?id=EJ665132

Bryant, A., \& Charmaz, K. (2007). Grounded theory research: Methods and Practices. In A. Bryant, \& K. Charmaz (Eds.), The SAGE handbook of grounded theory (pp. 1-28). London, UK: SAGE.

Cajete, G. (1999). Igniting the sparkle: An Indigenous science education model. Skyland, NC: Kivaki Press.

Castagno, A., \& Brayboy, B. (2008). Culturally responsive schooling for Indigenous youth: A review of the literature. Review of Educational Research, 78(4), 941-993. doi:10.3102/0034654308323036

Castellano, M. B. (2000). Updating Indigenous traditions of knowledge. In G. J. S. Dei, B. L. Hall, \& D. G. Rosenberg (Eds.), Indigenous knowledges in global contexts: Multiple readings of our world (pp. 21-36). Toronto, ON: University of Toronto Press. 
Creswell, J. W. (2014). Research design: Qualitative, quantitative and mixed methods approaches $\left(4^{\text {th }}\right.$ ed). Thousand Oaks, CA: Sage.

Dei, G. J. S. (Ed). (2011). Indigenous philosophies and critical education: A reader. New York, NY: Peter Lang.

Demmert, W. G. D., Jr. (2011). What is culture-based education? Understanding pedagogy and curriculum. In J. Reyhner, W. S. Gilbert, \& L. Lockard (Eds.), Honouring our heritage: Culturally appropriate approaches for teaching Indigenous students (pp. 109). Flagstaff, AZ: Northern Arizona University.

Donald, D. (2012). Indigenous Métissage: A decolonizing research sensibility. International Journal of Qualitative Studies in Education, 25(5), 533-555. http://dx.doi.org/10/1080/09518398.2011.554449

Ermine, W. (1998). Pedagogy from the ethos: An interview with Elder Ermine on language. In L. A. Stiffarm (Ed.), As we see ... Aboriginal pedagogy (pp. 9-28). Saskatoon, SK: University of Saskatchewan Extension Press.

Hammond, Z. (2015). Culturally responsive teaching and the brain: Promoting authentic engagement and rigor among culturally and linguistically diverse students. Thousand Oaks, CA: Corwin.

Hampton, E. (1995). Towards a redefinition of Indian education. In M. Battiste \& J. Barman (Eds.), First Nations education in Canada: The circle unfolds (pp. 5-46). Vancouver, BC: University of British Columbia Press.

Iseke, J. M., \& Desmoulins, L. (2015). A two-way street: Indigenous knowledge and science take a ride. Journal of American Indian Education, 54(3), 31-53.

https://www.jstor.org/stable/10.5749/jamerindieduc.54.3.0031\#metadata_info_tab_conte nts

Kirkness, V. J. (1998). Our peoples' education: Cut the shackles; cut the crap; cut the mustard. Canadian Journal of Native Education, 22(1), 10-15. https://eric.ed.gov/?id=EJ570804

Lee, T. S., \& McCarty, T. L. (2017). Upholding Indigenous education sovereignty through critical culturally sustaining/revitalizing pedagogy. In D. Paris \& H. S. Alim (Eds.), Culturally sustaining pedagogies: Teaching and learning for justice in a changing world (pp. 61-82). New York, NY: Teachers College Press.

McCarty, T. L., \& Lee, T. S. (2014). Critical culturally sustaining/revitalizing pedagogy and Indigenous education sovereignty. Harvard Educational Review, 84(1), 101-124. https://doi.org/10.17763/haer.84.1.q83746n15pj34216

National Centre for Collaboration in Indigenous Education (NCCIE). (2019, August). National Centre for Collaboration Indigenous Education. https://www.nccie.ca /

National Indian Brotherhood (NIB). (1972). Indian control of Indian education: Policy paper presented to the minister of Indian and Northern Development. Ottawa, ON: National Indian Brotherhood. http://www.oneca.com/IndianControlofIndianEducation.pdf

Northern Nishnaabe Education Council (NNEC). (2014). Pelican Falls First Nations High School. http://www.nnec.on.ca/index.php/pelican-falls-first-nations-high-school/ 
Nishnawbe Aski Nation (NAN). (2012). Nishnawbe Aski Nation's report on the challenges and needs in kikinahamaagewin (education). http://www.nan/on/ca /article/resources-andreports-402.asp

Nishnawbe Aski Nation (NAN) (2018). Agreement-in-principle. http://www.nan.on.ca/upload/documents/gs-nan-can-ed-jur-aip-final-may-31-2018 .pdf

Nuri-Robins, K. J., Lindsey, D. B., Lindsey, R. B., \& Terrell, R. D. (2011). Cultural proficient instruction: A guide for people who teach $\left(3^{\text {rd }}\right.$ ed.). Thousand Oaks, CA: Cowin Press, SAGE.

Rix, E. F., Wilson, S., Sheehan, N., \& Tujague, N. (2018). Indigenist and decolonizing research methodology. In P. Liamputtong (Ed.), Handbook of research methods in health social sciences. Singapore: Springer.

Royal Commission on Aboriginal Peoples (RCAP). (1996). Report of the Royal Commission on Aboriginal Peoples, (vol. 3). Ottawa, ON: Minister of Supply and Services Canada.

Savin-Baden, M., \& Major, C. H. (2013). Qualitative research: The essential guide to theory and practice. New York, NY: Routledge.

Sholey, L. (2018). "Incomprehensible failure": Auditor general says federal government not improving life for Indigenous people. APTN News. https://aptnnews .ca/2018/05/29/incomprehensible-failure-auditor-general-says-federal-government-notimproving-life-for-indigenous-people/

Staniforth, J. (2019). Where ancient knowledge lives on. Northern Ontario Travel. https://www.northernontario.travel/indigenous/manitou-mounds-northwest-ontario- skay-nah-chi-wah-nung-historical-centre

Styres, S., Haig-Brown, C., \& Blimkie, M. (2013). Toward a pedagogy of land: The urban context. Canadian Journal of Education, 36(2), 34-67. http://journals.sfu.ca/cje/index.php/cje-rce/article/view/1293/1528

Terrell, R. D., \& Lindsey, R. B. (2009). Culturally proficient leadership: The personal journey begins within. Thousand Oaks, CA: Corwin Press, SAGE.

The Truth and Reconciliation Commission of Canada (TRC). (2015). Truth and reconciliation commission of Canada: Calls to action. http://trc.ca/assets/pdf/Calls_to_Action_English2.pdf

White, J. P., \& Peters J. (2009). A short history of Aboriginal education in Canada. In J. P. White, J. Peters, D. Beavon, \& N. Spence (Eds.), Aboriginal education: Current crisis and future alternatives (pp. 13-31). Toronto, ON: Thompson Education.

Wilson, S. (2008). Research is ceremony: Indigenous research methods. Black Point, NS: Fernwood.

Wilson, S. (2016). Using Indigenist research to shape our future. In M. Gray, J. Coates, M. Yellowbird, \& T. Hetherington (Eds.), Decolonizing social work (pp. 311-322). New York, NY: Routledge. 